Nigerian Journal of Physiological Sciences 24 (2): 195 -202 @Physiological Society of Nigeria, 2009

Available online/abstracted at http://www.bioline.org.br/np; www.ajol.info/journals.njps; www.cas.org

\title{
EFFECT OF OCCUPATIONAL EXPOSURE TO LOCAL POWDERED TOBACCO (SNUFF) ON PULMONARY FUNCTION IN SOUTH EASTERN NIGERIANS
}

\author{
S. O. MADUKA ${ }^{1}$, E. E. OSIM ${ }^{2}$, R. O. NNELI ${ }^{3}$ AND A. E. ANYABOLU ${ }^{4}$ \\ Department of Physiology ${ }^{l}$, College of Health Sciences, Nnamdi Azikiwe University Nnewi Campus. \\ Department of Physiology ${ }^{2}$, College of Medical Sciences, University of Calabar Nigeria. \\ Department of Physiology, College of Medicine \& Health Sciences, Abia State University Uturu, Nigeria \\ Department of Anatomy, College of Health Sciences, Nnamdi Azikiwe University, Nnewi Campus, Nigeria
}

\begin{abstract}
Summary: The effect of occupational exposure to local powdered tobacco (snuff) on pulmonary function was studied. Snuff industry workers in Onitsha and Enugu markets were studied and compared with age-, weight-, and height-matched control not exposed to any known air pollutant. The pulmonary indices studied include; forced vital capacity $(\mathrm{FVC})$, forced expiratory volume in one second $\left(\mathrm{FEV}_{1}\right)$ and ratio of $\mathrm{FEV} / \mathrm{FVC}$ as percentage using a vitalograph spirometer and Peak Expiratory Flow Rate (PEFR), using a mini Wright Peak Expiratory Flow Meter. The respiratory and non-respiratory symptoms frequently associated with these workers were also analyzed and dust sampling in both test and control environments was also done. The mean anthropometric parameters, (age, height and body weight) between the two groups were not statistically different. The results obtained showed statistically significant impairment of lung function of workers chronically exposed to snuff. FVC, $\mathrm{FEV}_{1}$ and PEFR in the exposed (test) subjects were significantly decreased in comparison with the control subjects $(\mathrm{P}<0.05)$. However, the mean value of $\mathrm{FEV}_{1} / \mathrm{FVC}(\%)$ of the test subjects was $86.8 \%$ which was within the normal range and was not significantly different from control. This signified that the test subjects had restrictive pattern of lung function defect. All respiratory symptoms, such as cough, chest tightness had a higher prevalence in test subjects than their control group. The lung function indices of snuff-producing workers proportionately decreased with their length of exposure in the industry. The respirable dust level in the vicinity (indoor) of the snuff-workers $\left(1.11 \pm 0.35 \mathrm{mg} / \mathrm{m}^{3}\right)$ was significantly higher than in the control environment, $\left[\left(0.37 \pm 0.086 \mathrm{mg} / \mathrm{m}^{3}\right)(\mathrm{P}<0.001)\right]$. Although it was not possible to determine all the factors that may be responsible for lung function impairment, the dust sampling result showed that chronic exposure to Nigerian snuff (powered tobacco) dust impairs lung function and the effect is progressive with time.
\end{abstract}

Key words: Lung function, Snuff, Occupation, Symptoms

\section{Introduction:}

Snuff (powered tobacco with some additives) has been recommended as nicotine substitute of cigarette that is devoid of hazardous elements such as tar and carbon monoxide (Russel et al, 1980). The absorption of snuff is sometimes considered inefficient to provide an adequate nicotine substitute (Armitage et al 1978; Turner et al 1985). Snuffing has become quite popular as a medication for long grief, pain and aches (Tuner et al, 1985). It has been reported that $12.6 \%$ of students between 14 and 19 years of age in England use snuff (Paulson et al 1984) in the studied population. The widespread use of tobacco in Nigeria is well known. Owing to the high demand for snuff, there is a corresponding maintenance of a high supply by those employed in Snuff producing industry.

In most major markets in the South-Eastern Nigeria especially in Onitsha, Enugu and Aba, snuff producing industries abound. Each industry employs about 1000- 2000 workers in each market. Majority of these workers are men with very few women who work together in groups in the snuff industry using grinding, blending and mixing machines. Dried tobacco leaves are used to produce the snuff. During the process, snuff dust saturates and pollutes the entire atmosphere and beyond. The employees of the industry form isolated groups using special pestle and mortar to produce snuff by pounding dried tobacco leaves for hours and sieving the snuff dust, thereby inhaling high doses of dust.

Many of these snuff producers have been employed in the industry for upward of more than twenty years. They are regularly exposed to the risk of inhaling high doses of snuff dust over a long period. Although there are several reports on the harmful effects of exposure to tobacco/cigarette smoke (Tredaniel et al, 1994; Wells, 1994) and flue curing of tobacco in preparation for export (Osim et al, 1998), no reports have been found on the effect of occupational exposure to the preparation of Nigerian snuff (powdered tobacco with some additives) on the lung function of exposed workers.

Owing to the fact that the respiratory tract has direct contact with the environment, it is often the site of injury from occupational exposure (Wang et al, 1998; Horak et al, 2000). Snuff (powered tobacco) contains nicotine which is toxic in 
S. O. MADUKA et al

addition to other elements, e.g. natron, locally called "kanwa". Inhalation of potentially toxic materials in the work places can lead to major lung diseases (Musk et al, 1980; Crosbie 1986; Meister, 1990; Osim et al, 1992; Nowak 1998; Osim et al, 1996). Virtually all the workers in the snuff industry in the locality studied were unaware of potential harmful effect of exposure to snuff over a long period. There are no precautionary measures aimed at protecting workers at their work place owing to ignorance of the health implication of inhaling such high doses of tobacco dust for a long time. Winn et al (1981) reported increased mortality from oral and pharyngeal cancers in a case-controlled study of use of snuff. Nigerian powered tobacco contains other additives like natron and there are no studies on the effect of the local snuff exposure on lung function.

Although not on long function, a limited number of studies have been undertaken to determine the physiological and pharmacological effects of natron. In one of such studies, Oyeleke (1988) revealed that with chronic natron ingestion, there were severe growth retardation, skin changes and diarrhoea. Soladoye and Oyeleke (1989) showed that moderate intake of natron had adverse effects on growth rate and blood indices in rats even when diarrhoea was absent as earlier reported by Oyeleke (1988). The habitual consumption of natron was reported by Davidson et al (1974) to have contributed to the incidence of peripartal cardiac failure in Zaria and Malumfashi areas of Northern Nigeria. Therefore the aim of this study was to determine the lung function status as well as respiratory and other associated symptoms of workers occupationally exposed to Nigerian snuff dust (powered tobacco) in Onitsha and Enugu markets of South Eastern Nigeria.

\section{Materials and methods}

The study was carried out on workers occupationally exposed to snuff. A total of one hundred and twenty one were selected for the study. The control group consisted of seventy-five age-, height-, and weight-matched healthy people who are not occupationally exposed to snuff or any other air pollutant. The anthropometric parameters i.e. age, height and weight of test and control groups were similar. Those included in the test group were workers in the industry who were willing to participate fully in the study and were of Igbo extraction. Cigarette smokers and physically deformed workers were excluded from the study since these parameters affect lung function.

Having obtained the necessary ethical clearance from the Ethical Committee of Abia State University Uturu, the study was conducted in the premises of snuff producing industries in Onitsha and Enugu markets. A standard questionnaire on respiratory symptoms, knowledge and attitude of snuff producing workers with regards to hazards and protective measures was given to each subject to respond to under guidance. Weight of each subject was recorded in kilograms with the subject wearing light clothing and without shoes. Standing height of every subject was taken with a nonstretable meter rule. Pulse rate, respiratory rate and blood pressure were taken. Forced vital capacity (FVC), Forced Expiratory volume in one second $\left(\mathrm{FEV}_{1}\right)$ and the ratio of $\mathrm{FEV}_{1}$ to $\mathrm{FVC}$ as a percentage were used to assess lung function. A vitalograph spirometer (Spiro vit SP by Schiller, UK) was used for the measurements of the abovestated lung function indices. A mini-Wright peak flow meter (Air med Clement International, UK) was used to measure PEFR to add to the abovelisted lung function parameters.

\section{Test Procedure}

Before testing, the purpose of the test was explained to each subject and the method of testing demonstrated as well. For the measurement of peak expiratory flow rate PEFR), the subject was seated on a straight back chair and his or her belt loosened. The subject breathed in as much as possible, and applied his or her lips firmly around the mouth piece to prevent any air leak and breathed out as quickly and forcefully as possible into the peak flow meter with his or her nose clipped to prevent loss of air through the nose. While the subject was doing this, a check was made for air leaks around the mouth piece, and if detected the blow was repeated. Each subject performed three blows with a minimum of five minutes interval between each blow to allow the subject adequate rest. The best of the three readings was taken. FVC and $\mathrm{FEV}_{1}$ were obtained from each subject using a vitalograph spirometer and following the same procedure described above for PEFR (Hertzberg, 2002). $\mathrm{FEV}_{1} \%$ was computed from $\mathrm{FEV}_{1}$ and FVC.

\section{Dust Measurement}

Respirable dust level was determined at the sites of work of the snuff producers to establish the concentration of air-bone particles. This was done using "Haz-Dust Monitor" (Environmental Device Corporation, U.S.A., Model No: HDNOO serial No. - 298622). Range of measurement was 0$10 \mu \mathrm{m}$. This hazardous dust monitor is a possible direct reaching particulate monitor that uses infrared electronmagnetic radiation to sense the airborne particulates. The sensing method is technically referred to as forward light scattering. The infrared source and photo detectors are positioned at $90^{\circ}$ to each other. As the particulates intersect the sensing values, they scatter the light in a forward angle of $45-90^{\circ}$, the amount of scattering being proportional to hazardous dust concentration in the air. The dust concentration readout was 
Powdered tobacco and pulmonary function

expressed in milligram per cubic meter $\left(\mathrm{mg} / \mathrm{m}^{3}\right)$. The dust measurement was done at all the sites of snuff production and in areas where control subjects were exposed to serve as control for the snuff production sites.

\section{Statistical Analysis}

The student's unpaired t-test was used for the comparison of ventilatory function induces, and dust levels in the control of and test environments. Chi-squire test was used to test significance between percentages. Then data were presented as mean \pm standard error of the mean (SEM). A in Pvalue of $<0.05$ was considered as significant.

\section{Results}

\section{Study Population}

A total of 121 workers occupationally exposed to snuff and 75 control subjects, not exposed were evaluated in the two study centres; Onitsha snuff production industry and that of Enugu. All were south-eastern Nigerians of Igbo origin.

The age distribution of workers in the snuff industry and control is shown in table 1. The highest number of persons among age range was 40-49years which contributed 47 workers followed closely by the age range of 30-39 that had 41 workers. These age ranges constituted more than $70 \%$ of the study population. Snuff producing workers less than 29 years of age contributed less than $10 \%$ of the study population. These workers were therefore in the prime of their life. The mean

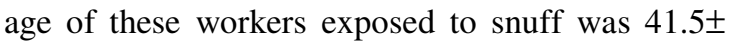
6.2 years. The youngest was 25years and oldest 58years. In the control subjects the age range that contributed the least was 20-29 and they contributed $5.3 \%$ and the range of 30-39years contributed the highest which was $33 \%$. The mean age of the control subject was $40.4 \pm 8.4$ years. The youngest was 22years and oldest 57 years. This mean age of the control subjects was not statistically significant when compared with the population exposed to snuff $(\mathrm{P}>0.5)$.

Table 2 shows that the mean body weights of the test group (exposed workers) and their control $(70.5 \pm 7.6$ vs $71.9 \pm 9.3 \mathrm{~kg}$ respectively) were also not significantly different. The majority $(79.3 \%)$ of the exposed workers fell within 60-79 $\mathrm{kg}$ body weight. A similar percentage $(73.3 \%)$ fell within the same body weight range among the control group.

Table 3 shows the distribution of the subjects studied into different height ranges. The mean heights of the test group and their control (168.5 \pm 5.0 vs $169.0 \pm 5.2$ respectively) were also not significantly different. The height range of 160-169 $\mathrm{cm}$ had majority of the exposed workers $(65.2 \%)$ and their control (58.7\%).
Table 1: Age Distribution of Snuff Producers and the Control Subjects.

\begin{tabular}{|l|c|c|c|c|c|}
\hline $\begin{array}{l}\text { Age } \\
\text { Group }\end{array}$ & Exposed & $\%$ & Control & $\%$ & Total \\
\hline $20-29$ & 7 & 5.8 & 4 & 5.3 & 11 \\
\hline $30-39$ & 41 & 33.9 & 33 & 44 & 67 \\
\hline $40-49$ & 47 & 38.8 & 28 & 37.3 & 67 \\
\hline $50-59$ & 26 & 21.5 & 10 & 13.3 & 36 \\
\hline Total & 121 & 100 & 75 & 100 & 196 \\
\hline $\begin{array}{l}\text { Mean } \\
\text { age } \\
\text { 土SD }\end{array}$ & $41.5 \pm 6.2$ & & $40.4 \pm 8.4$ & & \\
\hline $\begin{array}{c}\text { P- } \\
\text { value }\end{array}$ & \multicolumn{75}{|c|}{$>0.05$} & & \\
\hline
\end{tabular}

Table 2: Distribution of exposed and control subject according to weight.

\begin{tabular}{|c|c|c|c|}
\hline Wt $(\mathrm{kg})$ & Exposed & Control & Total \\
\hline$<50$ & 1 & - & 1 \\
\hline $50-59$ & 6 & 5 & 11 \\
\hline $60-69$ & 49 & 23 & 72 \\
\hline $60-79$ & 47 & 32 & 79 \\
\hline $80-89$ & 17 & 12 & 29 \\
\hline $90-99$ & 1 & 3 & 4 \\
\hline Total & 121 & 75 & 196 \\
\hline $\begin{array}{c}\text { Mean } \\
\text { wt } \pm \text { SD }\end{array}$ & $70.5+7.6 \mathrm{~kg}$ & $71.9+9.3 \mathrm{~kg}$ & \\
\hline P-value & $>0.05$ & \\
\hline
\end{tabular}

Table 3: Distribution of exposed subjects and control According to height

\begin{tabular}{|l|c|c|c|}
\hline $\begin{array}{c}\text { Height } \\
(\mathrm{cm})\end{array}$ & Exposed & Control & Total \\
\hline $150-159$ & 4 & 2 & 6 \\
\hline $160-169$ & 79 & 44 & 63 \\
\hline $170-179$ & 35 & 28 & 123 \\
\hline $180-189$ & 3 & 1 & 4 \\
\hline Total & 121 & 75 & 196 \\
\hline $\begin{array}{l}\text { Mean } \\
\pm \text { SD }\end{array}$ & $168 \pm 5.0 \mathrm{~cm}$ & $\begin{array}{c}169 \pm 5.2 \\
\mathrm{~cm}\end{array}$ \\
\hline P-value & \multicolumn{3}{|c|}{$>0.05$} \\
\hline
\end{tabular}

Table 4 shows that the mean FVC for workers exposed to snuff was $2.67 \mathrm{~L} \pm 0.6 \mathrm{~L}$ while that of the control subjects was $3.61 \mathrm{~L} \pm 0.58 \mathrm{~L}$. There was therefore a significant difference between the FVC of the two groups $(\mathrm{p}<0.001)$. The same pattern was also observed in the $\mathrm{FEV}_{1}$ which was $2.3 \pm 0.53 \mathrm{~L}$ for the exposed subject and $3.07 \pm 0.5 \mathrm{~L}$ for the control group. Another important index of lung function was the peak expiratory flow rate (PEFR). The value of PEFR of the exposed subjects as shown by table 4 was significantly different from the control; $(379 \pm 70.5 \mathrm{~L} / \mathrm{min}$ vs $511.3 \pm 86.8 \mathrm{~L} / \mathrm{min}$ respectively; $\mathrm{p}<0.001)$. Every index of respiratory 
S. O. MADUKA et al

function showed a significant difference between the exposed and the control $(\mathrm{P}>0.001)$. However, the ratio of $\mathrm{FEV}_{1} / \mathrm{FVC}$ expressed as percentage showed no significant difference between the exposed and the control $(86.8 \pm 6.64 \%$ vs $84.3 \pm 6.08 \%$ respectively.

Table 4: Summary of Anthropometric measurement and Lung function indices compared between exposed and control subjects.

\begin{tabular}{|c|c|c|c|}
\hline Parameter & $\begin{array}{l}\text { Exposed } \\
\text { subjects } \\
\text { mean } \\
\pm S D\end{array}$ & $\begin{array}{c}\text { Control } \\
\text { subjects } \\
\text { mean } \pm S D\end{array}$ & $P$-value \\
\hline Age (years) & $41.5 \pm 6.2$ & $40.6 \pm 8$ & $\begin{array}{c}\mathrm{P}>0.05 \\
(\mathrm{NS})\end{array}$ \\
\hline $\begin{array}{c}\text { Body Weight } \\
(\mathrm{kg})\end{array}$ & $70.3+7.6$ & $71.9 \pm 9.3$ & $\begin{array}{c}\mathrm{P}>0.05 \\
(\mathrm{NS})\end{array}$ \\
\hline $\begin{array}{c}\text { Duration of } \\
\text { Exposure } \\
\text { (years) }\end{array}$ & $9.5 \pm 3.9$ & $\begin{array}{c}\text { Not exposed } \\
\text { to any } \\
\text { known air } \\
\text { pollutant }\end{array}$ & NA \\
\hline Height (m) & $1.68 \pm 0.05$ & $1.69 \pm 0.052$ & $\begin{array}{c}\mathrm{P}>0.05 \\
(\mathrm{NS})\end{array}$ \\
\hline $\mathrm{FVC}(\mathrm{L})$ & $2.67 \pm 0.6$ & $3.61 \pm 0.58$ & $\begin{array}{c}\mathrm{p}<0.001 \\
(* *)\end{array}$ \\
\hline $\mathrm{FEV}_{1}(\mathrm{~L})$ & $2.3 \pm 0.53$ & $3.07 \pm 0.521$ & $\begin{array}{c}\mathrm{p}<0.001 \\
(* *)\end{array}$ \\
\hline $\begin{array}{c}\mathrm{FEV}_{1} / \mathrm{FVC} \\
(\%)\end{array}$ & $86 . \pm 6.64$ & $84.3 \pm 6.08$ & $\begin{array}{c}\mathrm{P}>0.05 \\
(\mathrm{NS})\end{array}$ \\
\hline $\begin{array}{c}\text { PEFR } \\
(\mathrm{L}) / \mathrm{min})\end{array}$ & $379 \pm 70.5$ & $551 \pm 86.8$ & $\begin{array}{c}\mathrm{P}<0.001 \\
(* *)\end{array}$ \\
\hline
\end{tabular}

$* *=P<0.001$ when compared with control; NS $=$ Not statistically significant when compared with control

Table 5: Respiratory symptoms / signs compared between exposed and control subjects.

\begin{tabular}{|c|c|c|c|}
\hline Symptom & $\begin{array}{c}\text { Exposed } \\
\text { subjects } \\
N=121(\%)\end{array}$ & $\begin{array}{c}\text { Control } \\
\text { subjects, } \\
N=75 \\
(\%)\end{array}$ & $p$-value \\
\hline $\begin{array}{c}\text { Persistent } \\
\text { cough }\end{array}$ & $44(36.4 \%)$ & $15(20 \%)$ & $\mathrm{P}<0.05^{*}$ \\
\hline $\begin{array}{c}\text { Frequent } \\
\text { Sneezing }\end{array}$ & $67(55.4 \%)$ & $21(28 \%)$ & $\mathrm{P}<0.001^{*}$ \\
\hline Wheezing & $23(19 \%)$ & $5(6.7 \%)$ & $\mathrm{P}<0.05^{*}$ \\
\hline $\begin{array}{c}\text { Chest } \\
\text { Tightness }\end{array}$ & $25(20.7 \%)$ & $6(8 \%)$ & $\mathrm{P}<0.05^{*}$ \\
\hline $\begin{array}{c}\text { Sputum } \\
\text { production }\end{array}$ & $33(27.3 \%)$ & $9(12 \%)$ & $\mathrm{P}<0.001^{*}$ \\
\hline $\begin{array}{c}\text { Running } \\
\text { Nose }\end{array}$ & $53(43.8)$ & $19(25.3 \%)$ & $\mathrm{P}<0.001^{*}$ \\
\hline $\begin{array}{c}\text { Breathless } \\
\text { on Level } \\
\text { ground. }\end{array}$ & $19(15.7 \%)$ & $5(6.7 \%)$ & $\mathrm{P}<0.05^{*}$ \\
\hline
\end{tabular}

* Statistically significant when compared with control.
Table 6: Correlation of anthropometric Measurement and Duration of Exposure with Lung Function parameters among the Exposed group

\begin{tabular}{|c|c|c|c|c|}
\hline \multirow{2}{*}{$\begin{array}{c}\text { Anthropometric } \\
\text { measurements/ } \\
\text { Exposure } \\
\text { Duration }\end{array}$} & \multicolumn{4}{|c|}{ Lung Function parameters } \\
\hline & FVC & $\mathrm{FEV}_{1}$ & $\begin{array}{l}\mathrm{FEV}_{1} / \\
\text { FVC }\end{array}$ & PEFR \\
\hline $\begin{array}{l}\text { Duration } \\
\text { exposure }\end{array}$ & $\begin{array}{l}\mathrm{r}=-0.3 \\
\mathrm{p}<0.01 \\
*\end{array}$ & $\begin{array}{l}r=-0.25 \\
N S\end{array}$ & $\begin{array}{l}\mathrm{r}= \\
+0.1 \\
\mathrm{NS}\end{array}$ & $\begin{array}{l}\mathrm{r}= \\
0.23 \\
\mathrm{p}<0.0 \\
2 *\end{array}$ \\
\hline Age & $\begin{array}{l}\mathrm{r} \quad= \\
0.17 \\
\mathrm{p}<0.01 \\
*\end{array}$ & $\begin{array}{l}r=0.18 \\
N S\end{array}$ & $\begin{array}{l}r=- \\
0.05 \\
\text { NS }\end{array}$ & $\begin{array}{l}\mathrm{r}= \\
0.15 \\
\mathrm{NS}\end{array}$ \\
\hline Height & $\begin{array}{l}\mathrm{r}= \\
+0.28 \\
\mathrm{p}<0.01 \\
*\end{array}$ & $\begin{array}{l}\mathrm{r}=+0.3 \\
\mathrm{NS}\end{array}$ & $\begin{array}{l}\mathrm{r}= \\
+0.11 \\
\mathrm{NS}\end{array}$ & $\begin{array}{l}\mathrm{r}= \\
+0.34 \\
\mathrm{p}<0.0 \\
1 *\end{array}$ \\
\hline Weight & $\begin{array}{l}\mathrm{r}= \\
+0.09 \\
\mathrm{NS}\end{array}$ & $\begin{array}{l}\mathrm{r} \\
+0.09 \\
\mathrm{NS}\end{array}$ & $\begin{array}{l}r= \\
+0.00 \\
5 \\
\mathrm{NS}\end{array}$ & $\begin{array}{l}\mathrm{r}= \\
+0.15 \\
\mathrm{NS}\end{array}$ \\
\hline
\end{tabular}
significant.

The respiratory symptoms of snuff exposed subjects and their control are shown in table 5. The prevalence of respiratory symptoms was $84.2 \%$ in the exposed workers against $33.5 \%$ observed in their control group. The difference was significant $(\mathrm{p}<0.001)$. With regards to specific symptoms frequent sneezing (nasal stuffiness) has the highest frequency of $55.4 \%$. This is followed by running nose $(43.8 \%)$ and then persistent cough (36.4\%). $27.3 \%$ complained of sputum production, $207 \%$ had complaint of chest tightness. Others are wheeze $(19 \%)$ and breathless on level ground $18.7 \%$. Compared with the control subjects, there were statistically significant differences in all the symptoms when the test subjects were compared with their control $(\mathrm{p}<0.05-0.001)$.

Table 6 shows correlation of the anthropometric parameters with duration of exposure among the exposed workers in the snuff industry. It was noted that there was a negative correlation between the length of exposure and all the indices of lung function except $\mathrm{FEV}_{1} / \mathrm{FVC}$ expressed as a percentage. Thus, there was depreciation of lung function indices, namely; FVC, $\mathrm{FEV}_{1}$, and PEFR as the length of exposure increased. There was also a significant positive correlation of the height and age with some function indices, notably, FVC and $\mathrm{FEV}_{1}$. The correlation of body weight with the lung function indices was not significant in the study. 
Powdered tobacco and pulmonary function

Table 7 shows the correlation of anthropometric parameters with lung function indices among the control group. There was positive correlation of height and weight with FVC, $\mathrm{FEV}_{1}$ and PEFR. Age correlated significantly with $\mathrm{FEV}_{1} \%$.

Table 7: Correlation of Anthropometric Parameters with Lung Function among the Control Group

\begin{tabular}{|c|c|c|c|c|}
\hline \multirow{2}{*}{$\begin{array}{c}\text { Anthropometric } \\
\text { measurements }\end{array}$} & \multicolumn{4}{|c|}{ Lung Function parameters } \\
\hline & $F V C$ & $F E V_{l}$ & $\begin{array}{l}F E V_{l} \\
/ F V C\end{array}$ & PEFR \\
\hline Age & $\begin{array}{l}\mathrm{r}= \\
0.15 \\
\mathrm{NS}\end{array}$ & $\begin{array}{l}r \quad= \\
0.03 \\
N S\end{array}$ & $\begin{array}{l}r=0.30 \\
p<0.05^{*}\end{array}$ & $\begin{array}{l}r=0.13 \\
N S\end{array}$ \\
\hline Height & $\begin{array}{l}\mathrm{r}= \\
+0.39 \\
\mathrm{p}<0.0 \\
1 *\end{array}$ & $\begin{array}{l}\mathrm{r}= \\
+0.3 \\
\mathrm{p}<0.0 \\
1 *\end{array}$ & $\begin{array}{l}r=+0.09 \\
N S\end{array}$ & $\begin{array}{l}\mathrm{r}= \\
+0.45 \\
\mathrm{p}<0.01 \\
*\end{array}$ \\
\hline Weight & $\begin{array}{l}\mathrm{r}= \\
+0.34 \\
\mathrm{p}<0.0 \\
1 *\end{array}$ & $\begin{array}{l}r \quad= \\
+0.09 \\
N S\end{array}$ & $\begin{array}{l}r=0.09 \\
N S\end{array}$ & $\begin{array}{l}\mathrm{r}= \\
+0.36 \\
\mathrm{p}<0.01 \\
*\end{array}$ \\
\hline
\end{tabular}

Significant

\section{DISCUSSION}

Snuff industry workers are chronically exposed to high level of snuff dust. Such long term exposure to snuff dust has been shown to have deleterious effects on their lung health. It has been associated with high prevalence of respiratory symptoms and ventilatory function impairment, (Philips, 1998). However, these studies were not done on Nigerian workers. Nigerian snuff also known as powered tobacco contains some additives, notably, natron not found in snuff elsewhere.

This study has shown that workers in the snuff industry had a high rate of prevalence of respiratory symptoms when compared with control group. The prevalence of respiratory symptoms in the snuff industry was $88 \%$ while the control was $33 \%$. This difference was statistically significant $(\mathrm{p}<0.001)$. A similar work done by Walling (1981) produced less respiratory symptoms than this study. The reason for the high prevalence of symptoms likely to be due to high concentration of the snuff dust inhaled by these workers and the total lack of precautionary measures in the snuff producing industry in Eastern Nigeria. The high concentration of snuff (sometimes a single measure of up to $1.55 \mathrm{mg} / \mathrm{m}^{3}$ ) may be due to low level of roofs which made the escape of the snuff dust difficult. The results showed high prevalence of specific respiratory symptoms when compared with the control that was statistically significant. Other studies (Dool and Peto, 1985; Michael and Petty, 1982) have also shown a high prevalence of respiratory symptoms viz: cough, wheeze, sputum production and breathlessness among workers occupationally exposed to atmospheric pollutants like asbestos, saw dust and granite. The prevalence of respiratory symptoms of workers exposed to snuff dust was high in this study. The most prevalent was the nasal symptoms namely, frequent sneezing and running nose. Frequent sneezing constituted the highest (55.4\%), while running nose was $43.8 \%$, cough and sputum production constituted $36 \%$ and $33 \%$ respectively, chest tightness, $20.7 \%$ and breathlessness $15.7 \%$. It is likely therefore that the snuff contained irritants of the respiratory system.

Comparing the mean values of the four indices of lung function employed in this study with their control showed that the control group had higher mean values of FVC, $\mathrm{FEV}_{1}$, and PEFR than the snuff-producing workers. $\mathrm{FEV}_{1} \%$ in the two groups was not significantly different and was all in the normal range i.e. $86.8 \%$ for exposed workers and $84.3 \%$ for the control. This pattern of impaired ventilatory function is indicative of restrictive lung function defect - and is inconsonance with dust related exposure (Osim et al, 1992, 1996; Kunzli et al, 2000; Jinadu et al, 1988; Okwari et al, 2005). The absence of any incidence of obstructive respiratory defects like asthma supports the restrictive respiratory defect that is indicated in this study. This impairment in the lung function is not unexpected as snuff dust and its constituents cause allergic and non-allergic chronic inflammation of the respiratory airways of the lungs which affect their functions. (Okpapi and Bosan, 2004). Although, it was not possible to determine all the factors responsible for lung function impairment in snuff producing workers, dust sampling in both test and control environment suggested that chronic exposure to snuff dust was likely to be the causative factor. The indoor respirable dust level in the snuff industry was significantly higher than the control environment. $(\mathrm{p}<0.001)$. It has been established from various reports that anthropometric parameters viz; age, height, weight, sex and ethnicity are factors that can account for variation in FVC, $\mathrm{FEV}_{1}$ and PEFR. (Cotes, 1975; Aderele and Oduwole, 1983; Jaja and Fagbenro, 1995; Njoku and Anah, 2004). These factors were taken into consideration and so, were similar in the test and control groups.

Correlation tests showed that while the lung function of snuff workers significantly increased 
S. O. MADUKA et al

with height and body weight, it decreased with longer duration of exposure, and age. This means that with time the lung function impairment and respiratory symptoms in the snuff producing industry in the area studied will worsen. There is therefore the need to take precautionary measures, do frequent monitoring of lung function and redeploy subjects severely affected to other less hazardous areas.

In conclusion, chronic exposure to Nigeria powered tobacco dust (Snuff) without precautionary measures may impair lung function and provoke respiratory symptoms.

\section{References}

Aderele W.J. and Oduwole O. (1983) Peak Expiratory Flow. Rate in Healthy School Children. Nig. J. Paed., 105: 45-55.

Ahuja G.K. and Ahuia I.S.A (1983) "Comparative Study of Ventilatory Pulmonary Function Tests in Health and Disease in Nigerian males. West Afr. J. Med. 2: 61-65.

Akpaffiong, M.J. (1987) The diuretic, natriaretic and blood pressure effects of Trona in rat. $W$. Afr. J. of Pharm and Drugs Rest Vol. 7 (1): 914.

Amure B.O. (1990) Peptic Ulceration, cattle milk and the Fulani. Guest lecture and symposium during the 12th Annual Scientific conference of physiological society of Nigeria. University of Jos-Nigeria 8-10th Feb. 1990.

Armitage A., Dollery C., Tousenian T., Kohner R., Lewis P.J. Turner D. (1978) Absorption of nicotine from small cigars. Clin. Pharm. Ther. 23: 143-151.

Bhat, M.R. and Ransaswamy C. (1991) A comparative study of lung function in rice and saw mill workers. Indian J. Physiol Pharmacol; 35: 27-30.

Bhattacharve A.K. and Beneriee S. (1966) "Vital capacity in children and young adult in India. Indian L. Med. Res; 54: p 62.

Boewer, B.J., Byers, F.M. Schelling, (T) Coppock C.E. and Greens L.W. (1987) Trona and sodium bicarbonate in beef cattle diet: effect of PH and volate fatty acid concentrations J. Anim-Sci. 65(1): 309-316.

Bosan I.B. and Okpai J.U. (2004) "Respiratory sysmptom and ventilatory function among woodworkers in the Savanah Belt of Nigeria; Anal of Africa Medicine vol 3: (1): 22-27.

Burrows B. and Clone M.G.A. (1983) "Descriptive analysis of growth and decline of FVC and $\mathrm{FEV}_{1}$, Chest; 83. p. 717.
Cote J.E. 1975 Lung function Assessment and application Oxford, Blackwell scientific publication 3-5.

Crosbie W.A. (1986) "The respiratory health of carbon black workers" Arch. Environ.Health 41:346-353.

Dahlqvist, M. and Ulfarson U. (1994) Acute affect on forced expiratory volume in one second and longitudinal change in pulmonary function among wood traumas. Am. J. Ind. Med; 25 (4): 551-558.

Davidson N., Trevitt, L., Parry E.N. (1974) Peripartum cardiac failing. An explanation for the observed geographic distribution in Nigeria. Bull. WHO 51:203-208.

Davis, CL., Brown, R.E., Reitz, D.C. (1964). Effect of feeding higher grain restriction-roughage ratio with and without bicarbonate on the fats content of milk produced and proportions of volatile fatty acid in the skin. J. Dowry Sci No. 1. (Nov.) 1217 - 1220.

Demuth C.R. Howatt W.F., Hill C.M. (1965) “Lung Volumes" Paediatrics. 35: 162.

Doll R. and Peto J. (1985) "Effects on Health of Exposure to Asbestos, Health and Safety commission, Her Majesty's Stationary office London.

Donker J.D. and Marx CD (1985) Dietary sodium bicarbonate for high Producing Holstein cows over complete lactation. J. Dairy Sci. 68 (1): $140-146$.

Emery R.S. and Brown C.D. (1961) Feeding Sodium and Potassium bicarbonate on milk fat lumen $\mathrm{pH}$ and volatile fatty and production $J$. Dairy Sci. 44:1899.

Ele P.U. (1992). Reference values for FVC and $\mathrm{FEV}$, in male adolescent and young adult of Ibo origin. East Afr. Med J. 69: 2:105-109.

Faure, EAM; Lim, H.S.; Block, B.S. Tan, P.L. \& Roizen H.F. (1987) Sodium bicarbonate buffers gastric and during surgery in obstetric and gynaecology patron Anasthesiology. 62(2): 277.

Hertzberg V.S (2002) "Effects of occupational silica exposure on pulmonary function". Chest: 122 (2): 721-728.

Horak F.Jr., Studnocka M., Garlhuer C., Neuman M., Tauber E., Urbaneck R., Hinds D.D (1982). The use of Tobacco. Env. Health Perspect. 7782.

Jaja, S. I. and Fagbenro, A. O. (1995) Peak expiratory flow rate in Nigerian school children Afr. J. Med. Sci. 24:379-384.

Jinadu, MK, Owolabi, S.O. and Hossain M.Z. (1988) Respiratory function in wood furniture workers in Nigeria. W. Afr. J. Med. 7 (2): 104106. 
Powdered tobacco and pulmonary function

Johannsen ZM and Erasinus L.D. (1967), Clinical spirometry in normal Bantu, Am Rev. Respir Dis 97: 585-598.

Knudson R.J., Status R.C., Lebowitz M.D (1976) Maximal expiratory flow curve: normal standard, variability and effect of age. Am. Rev. Respir. Dis. 113:587-600.

Kumar P, and Clark M. (2005) Clinical Medicine; $6^{\text {th }}$ Ed. London: Elsevier Saunders. p. 893.

Kunzli N., Schwartz J., Stutz E.Z. (2000). Association of environmental tobacco smoke at work and forced expiratory lung function among never smoking asthmatics and non asthmatics. The SPALDIA Team Soc Praventia Med; 208-217.

Lazebnik N. (1986) Spontaneous rupture of normal stomach after $\mathrm{NaHCO}_{3}$ ingestion. J. Clin Gastroenterol. 8(4): 454-456.

Meister R. (1990) General environmental pollutants and passive smoking. Pneumologic 44 Suppl: 378-386.

McDavidson D. N. and Parry E. H. O. (1978). Peripartum cardiac failure. Quart. J. Med. New Series_XLVII No. 188.

Michael RS and Petty F.L (1982) Synopsia of Clinical Pulmonary Disease. $3^{\text {rd }}$ ed. London CV Mosby 25-27.

Musk A.W., Pefers J.M., Wegman D.H., Fine L.J (1980) Pulmonary function in granite dust exposure: a four-year follow up. Am. Rev. Respir. Dis. 115:769-776.

Njoku, CH. And Anah, C.O. (2004). Reference value for Peak expiratory flow rate in adults of African descent. Trop. Doctor 34:130-140.

Nowak L. (1998) Health Effects of airborne Pollutants particularly in swine confinement stalls from view point of occupational medicine. DTW Dtsch. Tieraztl Wochenschrs; 105:225-334.

Ofuya, Z. M. (1982). The effect of trona on thiamine retention in cooking cowpeas (Vigna unguiculata). Abstract. Proc. Physiol Soc. of Nig. 1982 C20//82 68 In: Niger. J. Physiol Sci. of Nigeria 1980-1982.

Okpapi J.U. and Bosan I.B. (2004). Respiratory symptoms and ventilator function impairment among wood workers in Savannah belt of Northen Nigeria. Ann. Afr. Med. 3 (1): 22-27.

Okwari, O.O., Autai, A.B., Owu, D.U. Peters E.J. Osim, E.E. (2005). Lung function status of workers exposed to wood dust in timber markets in Calabar Nigeria. Afr. J. Med. Sci., 34: 141-145.

Oyeleke, A.O. (1984). Textural properties of stored Kanwa-cooked cowpea foods Niger. J. Biochem. 1: 60-67.
Oyeleke, A. O. (1988). Effect of consumption of "Kanwa" in food and water on certain physiological states in rats Nutrition. 4: 137140.

Odunkor, P. O., Morgan, W. O, Palmer, L. T., Sankoko E.U (1997). Spirometric measurement in healthy Sierra Leonians. West Afr. J. Med 16(2): 112-116.

Onadeko, B. O., LVun A. A, Jofowora R. O., Adamu S. O., Ventilatory function in normal Nigerian children. Afr. J. Med Sci. 8: 25.

Osim E.E, Esim R.A. (1996) Lung function studies in some Nigerian bank workers Centr. Afr. J. Med. 42:43-46.

Osim E.E. Musabayane C.J., Mufunda (1998). Lung function of Zimbabwen Farm Workers exposed to Flue curing and stacking of tobacco leaves S. Afr. Med J. 88: 1127-1131.

Osim E.E., Esin R.A., Fossung F.E, Archibong E.I. (1992). Ventilatory function in Nigeria Absestos factory workers. East Afr. Med. J. 69: 42:43-46.

Osim E.E., Tandayi M., Chunyanga H.M., Matarira H.T., Mudambo K.K., Musabayane C.I. (1998) Lung function, blood gases, $\mathrm{pH}$ and serum electrolytes of small scale miners exposed to chrome ore dust on the Great Dyke in Zimbabwe. S. Afr. M.J. 88 (8): 1127-1131.

Parkes W.R. (1982) Occupational Lung Disorders. Butherworths 2: 222-224.

Patrick J.M. and Femi-Pearse D. (1976). Reference values for FVE and FEV, in Nigeria men and women: a graphical summary. Niger. Med J; 6: 380- 385.

Paulson T.C., Lindennith J.E., Green R.P. (1984). A comparison of use of smokeless tobacco in rural and urban teenagers. Children Angle 34:248.

Peters E.J., Esin R.A., Immananyagha K.K., Siziya S., Osim E.E., (1999). Lung function status of same Nigerian. Men and women chronically exposed to fish dying using burning firewood. Central Afr. J. Med 45(5):119-124.

Philips G. (1998). Snuffs and Snuffing. Personal Experiences of Snuff: 163-171.

Russel M.A.H., Tarvis M. Feyerabent C A view age for Snuff? (1980) Lancet. 1: 474-475.

Shoenbora J.B, Beck G.J. Bouhuas A. (1978) Growth and decay of pulmonary function in healthy blacks and whites. Resp. Physiol. 33: (3): 367-393.

Smoking and your Health (1961) A report of Royal College of Physicians. Pitman Med Pub. Co. London.

Soladoye A.O. and Oyeleke D.A. (1989) the effects of moderate intake of natron on growth rate and 
blood indices in rats. Proc. Int. Union Physiol Sci (xvii) p. 5421.

Solorzano, L.C. (1989) Sodium bicarbonate or sodium resbicarbonate on lactating Holsteins fed a high rain diet J. Dairy Sci. 72 (2): 483561.

Tonnetti, F. (1988). A case of stomach rupture after ingestion of $\mathrm{NaHCO}_{3}$ Minerva Chair 31:43(20) 1737-1739.

Tredaniel J. Ruffeta P., Saracci R., Hirsah A. (1994). Exposure to environmental tobacco smoke and adult non-neoplastic respiratory disease. Eur Respir J. 7:173-185.

Tuner K.A.M, Sillette R.N. McNicol M.W. (1985) Effect of Cigar smoking on carboxy haemoglobin and plasma nicotine concentrations in primary pipe cigar smokers and ex-smokers. Br. Med. J. 1077, ii 1387-1398.
Ursula B. (1990) Snuff Shive Publication (1) Veiter A, and Frisher T. (2000). The Effect of inhalable dust particles on lung function and respiratory symptoms of school children. Wein Klin Wocheusch: 126-32.

Walling A. (1981). Smokeless tobacco related health hazards from good old habit. J. Roy C. G. Pract 1086; 36:466-467.

Wang Z., Mannien A., Malberg P. and Larson K. (1998). Inhalation of house dust increases the concentration of interleukin-I-beta (IL-B) and interleukin -I-receptor antagonist (IL-Ira) in peripheral blood. Respir. Med. 92: 1022-1027.

Wells A.J. (1994). Passive smoking as a cause of heart disease. J. Am Coll Cardiol 24: 546-554.

Winn D.M., Blot W.J. Shy C.M. (1981). Snuff dipping and oral cancer among women in the southern United State N. Eng. J. Med._304:745749.

Received: November 6, 2009

Accepted: December 18, 2009 